Gatot Silo Sakti, Hari Rujito Dan Rahmat Ali Syaban, Analisis Rantai Nilai Hasil Tangkapan Lemuru Sebagai Bahan Baku Industri Pengolahan Ikan

\title{
ANALISIS RANTAI NILAI HASIL TANGKAPAN LEMURU SEBAGAI BAHAN BAKU INDUSTRI PENGOLAHAN IKAN
}

Oleh :

\section{GATOT SILO SAKTI*), HARI RUJITO DAN RAHMAT ALI SYABAN**)}

\begin{abstract}
ABSTRAK
Lemuru merupakan ikan ekonomis penting yang menjadi hasil tangkapan andalan masyarakat nelayan muncar untuk memenuhi kebutuhan ekonomi dan sebagai bahan baku utama industri pengolahan ikan, yang umumnya adalah industri pengalengan dan penepungan ikan. Tujuan dari penelitian ini adalah (1) mengidentifikasi permasalahan-permasalahan yang berkaitan dengan aktivitas-aktivitas yang berpotensi meningkatkan kesejahteraan nelayan melalui pemetaan rantai nilai, (2) menganalisis tata kelola dan regulasi yang selama ini berlaku dalam menjaga kelestarian jumlah lemuru, (3) Menganalisis elemen-elemen yang menjadi kekuatan pendorong dalam rantai nilai dan merumuskan strategi rantai nilai yang efektif guna mencapai kesejahteraan pelaku-pelaku di dalam rantai nilai.

Berdasarkan pemetaan rantai nilai, diketahui Pengelola Tempat Pelelangan Ikan (TPI) tidak berkontribusi dalam alur penjualan ikan, sehingga nelayan tidak memiliki perlindungan harga dalam menjual hasil tangkapannya. Dari pendapatan pakar melalui teknik analisis ISM (Interpretative Structural Modelling) terdapat empat elemen yang di identifikasi dalam kegiatan lemuru, yaitu : Elemen kendala dalam kegiatan perikanan lemuru dengan sub elemen lembaga terkait kurang optimal dalam mewujudkan solusi yang telah dirumuskan sebagai sub elemen kunci, Elemen kebutuhan pelaku usaha dalam kegiatan perikanan lemuru dengan sub elemen tata kelola, regulasi dan pengawasan, penyuluhan dan pembinaan, solusi dari peraturan yang ada, dan kelembagaan yang aktif merupakan sub elemen kunci.

Berdasarkan analisis strategi kebijakan melalui AHP (Analytic Hierarchy Process), kriteria kebijakan yang menjadi prioritas adalah kelesetarian lemuru dengan alternatif kebijakan yaitu law enforcement. Penerapan law enforcement dapat efektif apabila ditunjang kebijakan lain untuk memperkecil gap antara peraturan dengan pelanggaran. Kebijakan alternatif tersebut dapat dikelola secara bertahap dan sinergis, dimulai dari koordinasi stakeholder dalam rangka penguatan modal dengan mendirikan Lembaga Keuangan Mikro, penerapan open season dan close season, pengalihan wilayah tangkap untuk nelayan dan diversifikasi bahan baku untuk industri, mengembangkan potensi wisata pelabuhan untuk menyerap angkatan kerja selama kebijakan tersebut direncanakan, dan didukung dengan pembaharuan data pengukuran bioeconomic.
\end{abstract}

Kata Kunci : Rantai Nilai, Tata Kelola dan Regulasi, AHP, ISM

\section{PENDAHULUAN}

Lemuru (Sardinella Lemuru) merupakan jenis ikan yang spesifik dan hanya satu-satunya di Indonesia, habitat lemuru hanya dapat ditemukan di perairan Selat Bali. Peneliti sumberdaya perikanan mengungkapkan bahwa keberadaan Lemuru di Selat Bali tidak lepas dari jenis perairan yang kaya akan bahan makanan yang dibutuhkan oleh lemuru tersebut. Pada Tahun 1975-2007 lemuru yang berada di Selat Bali memiliki keunikan yaitu produksinya dapat mencapai rata-rata hampir $80 \%$ dari total produksi (Setyohadi Et al, 2009.

Penangkapan lemuru cukup berhasil untuk meningkatkan ekonomi masyarakat sekitar Muncar pada saar itu, tetapi lambat laun hasil tangkapan lemuru menurun tajam akibat penangkapan yang berlebihan (over fishing). Menurut Setyohadi et al (2007) tingkat pengusahaan lemuru di selat bali mencapai $233,4 \%$ sehingga status pengusahaannya sudah deplesi (depleted), berdasarkan pendekatan kelestariannya/MSY (Maximum Sustainable Yield) dan berdasarkan tingkat Ekonomi/MEY (Maximum Economic Yield) tingkat pengusahaannya berturut- turut sebesar 147,9\%, 267\%, 167\% sehingga status pengusahaannya sudah over exploited dan depleted, sedangkan berdasarkan kaidah sosial diperoleh tingkat pengusahaan sebesar $83,5 \%$ yang menunjukan perikanan pada kondisi tereksploitasi penuh.

Jumlah tangkapan lemuru yang semakin menurun jumlahnya menyebabkan kerugian bagi nelayan karena hasil penjualan lemuru tidak sebanding dengan biaya operasional yang telah dikeluarkan, oleh karena itu nelayan tidak memiliki cukup biaya operasional untuk melanjutkan penangkapannya. Berdasarkan data HNSI (Himpunan Nelayan Seluruh Indonesia, 2014) dari 170 armada purse seine yang ada hanya 79 armada yang mampu beroperasi. Demikian pula yang terjadi pada industri pengalengan ikan, pada tahun 2014 terdapat 59 perusahaan yang tidak dapat beroperasi dari 145 perusahaan yang terdata pada tahun 2007 . Hal disebabkan karena perusahaan kesulitan mendapatkan bahan baku dan biaya produksi yang cukup besar apabila perusahaan mengimpor bahan 
baku lemuru dari negara lain. (Lembaga Pengelola Sumberdaya Perikanan Berbasis Komunitas, 2014 dan Kedeputian Bidang Pengendalian Pencemaran Lingkungan, 2007).

Berdasarkan faktor kritis kelestarian lemuru, keberlanjutan kegiatan perikanan lemuru di sinyalir akan terancam secara kelestarian dan pemanfaatannya, sehingga akan berdampak pada menurunnya tingkat ekonomi masyarakat pesisir pantai Muncar

Oleh sebab itu diperlukan langkah strategi untuk melakukan pembaharuan atau peningkatan dalam merumuskan suatu konsep kebijakan untuk menyelesaikan permasalahan yang ada. Pendekatan yang tepat dalam mendalami permasalahan tersebut adalah pendekatan rantai nilai, dimana rantai nilai memiliki konsep mengkaji secara mendalam hubungan dan integrasi kegiatan yang ada dalam suatu usaha untuk mengukur efektifitas sejauh mana keberlangsungan usaha dapat dilaksanakan secara optimal dan bersinergi dengan pelaku yang terlibat, regulasi dan tata kelola yang telah di sepakati

\section{METODE PENELITIAN \\ Rancangan Penelitian}

Ranacangan penelitian ini adalah pengamatan langsung, wawancara pakar dan penyebaran kuesioner.

\section{Populasi, Sampel dan Teknik Pengambilan sampel}

Teknik pengambilan sampel menggunakan non probabillity sampling, yaitu snowball sampling dan purposive sampling. Snowball samping digunakan untuk mengidentifikasi anggota rantai nilai di kecamatan Muncar, Kabupaten Banyuwangi. purposive samping diambil berdasarkan beberapa kriteria tertentu yang telah ditetapkan. Pakar berperan penting dalam memberikan penilaian terhadap permasalahan yang ada. Pakar yang digunakan dalam penelitian ini sebanyak empat orang, yaitu : Ketua Himpunan Nelayan Seluruh Indonesia (HNSI), Tokoh Nelayan, Ketua melanjutkan analisis berikutnya. Temuan dilapangan mengenai kendala yang terjadi pada
Kelompok Nelayan Purse Seine, Kepala UPT Pelabuhan Perikanan Muncar. Kemudian diambil lagi dua orang pakar untuk pengolahan data AHP yaitu Kepala Departemen Perikanan dan Kelautan Banyuwangi dan Akademisi dan Peneliti Universitas 17 Agustus Banyuwangi.

\section{Instrumen Penelitian}

Sesuai dengan rumusan masalah, tujuan penelitian dalam penelitian ini digunakan instrumen kuesioner untuk memperoleh data untuk menentukan driver power dan struktur hirarki dalam teknik interpretative structural modellingdanrekomendasi kebijakan pada teknik analisis Analytic Hierarchy Process(AHP).

\section{Prosedur Pengumpulan Data}

1. Observasi dilaksanakan dengan pengamatan langsung pada objek penelitian untuk mengidentifikasi komoditas olahan ikan yang paling unggul di Pelabuhan Perikanan Pantai, Muncar.

2. Wawancara dilaksanakan dengan pihak pihak yang berkepentingan dalam rantai nilai, yaitu : Departemen Perikanan dan Kelautan, Pelabuhan Perikanan Pantai Muncar, kelompok nelayan dan pihak manajemen industri pengalengan ikan.

3. Data diperoleh dari sumber ahli terpercaya yang terkait dengan penelitian, yaitu : Kepala Departemen Perikanan dan Kelautan, Kepala Pelabuhan Perikanan Pantai Muncar, kelompok nelayan dan pihak manajemen industri pengolahan ikan

\section{HASIL DAN PEMBAHASAN \\ Pemetaan Rantain Nilai}

Analisis pemetaan rantai nilai merupakan gambaran atas keseluruhan yang terjadi pada kegiatan perikanan lemuru di Muncar, Banyuwangi. pada penelitian pemetaan rantai nilai bertujuan untuk mengungkap hambatan dan mengggali dimensi-dimensi yang dapat digunakan sebagai tolak ukur dan dasar untuk aktivitas perikanan lemuru dijelaskan pada matrik yang tersaji pada gambar 1 . 
Gatot Silo Sakti, Hari Rujito dan Rahmat Ali Syaban, Analisis Rantai Nilai Hasil Tangkapan Lemuru Sebagai Bahan Baku Industri Pengolahan Ikan

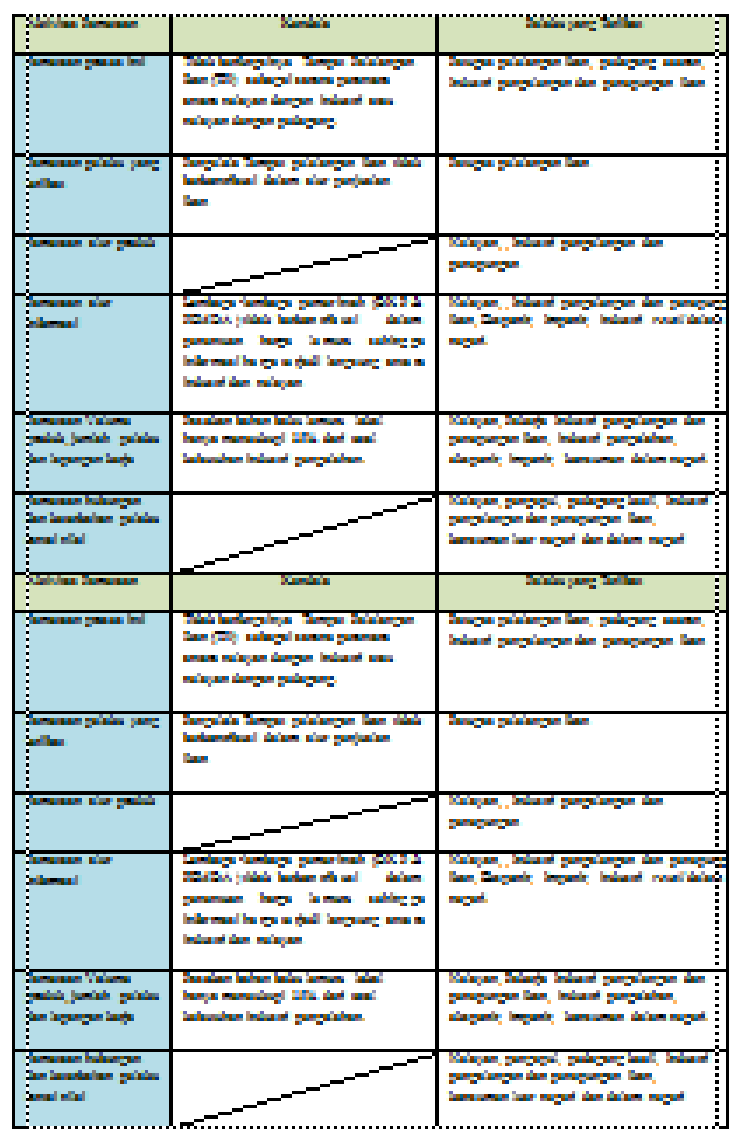

Gambar 1. Matriks Kendala Rantai Nilai Hasil Tangkapan Lemuru

Analisis Struktur Elemen-Elemen yang Terkait di Dalam Rantai Nilai

Interpretative structural modelling (ISM) merupakan suatu teknik permodelan untuk mengidentifikasi elemen-elemen yang kompleks di dalam rantai nilai, elemen-elemen tersebut merupakan suatu kesatuan di dalam rantai nilai yang memiliki pengaruh kuat terhadap mekanisme rantai nilai hasil tangkapan lemuru untuk bahan baku industri pengolahan ikan. Berdasarkan hasil analisis pakar, diperoleh empat elemen sistem yaitu

1. Elemen kendala dalam kegiatan perikanan lemuru

2. Elemen kebutuhan pelaku usaha dalam kegiatan perikanan lemuru

3. Elemen masyarakat yang terpengaruh di dalam rantai nilai

4. Elemen lembaga yang terlibat di dalam rantai nilai.

Dari keempat elemen tersebut masingmasing elemen dikaji dan diuraikan lagi menjadi sejumlah elemen berdasarkan pendapat para pakar, kemudian dilanjutan dengan penilaian hubungan konspetual antara sub elemen pada setiap elemen di dalam rantai nilai. Hasil dari kajian ini adalah model struktural rantai nilai hasil tangkapan lemuru untuk bahan baku industri pengolahan ikan yang berupa hirarki sub elemen dengan sub elemen
Tabel 1. Analisis Ragulasi dan Tata Kelola Rantai Nilai

\begin{tabular}{|c|c|c|c|c|}
\hline \multirow[t]{3}{*}{$\infty$} & \multicolumn{4}{|c|}{ 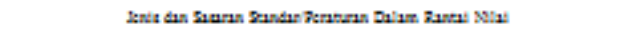 } \\
\hline & & \multirow{2}{*}{$\begin{array}{l}\text { Lemingi } \\
\text { Pengunas }\end{array}$} & & \multirow{2}{*}{ 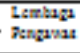 } \\
\hline & Seliy $1 \mathrm{n}$ & & 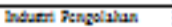 & \\
\hline 1 & 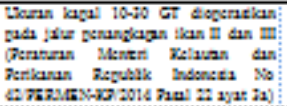 & $\begin{array}{l}\text { Polland } \\
\text { of } \\
\text { 7elitudan }\end{array}$ & 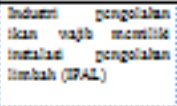 & 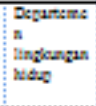 \\
\hline 2 & 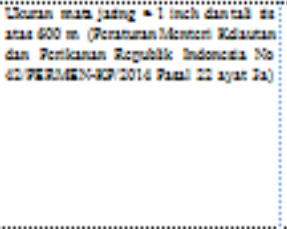 & 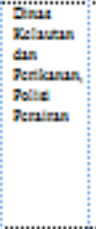 & 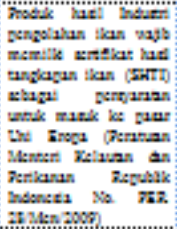 & $\begin{array}{l}\text { Deivas } \\
\text { Jas } \\
\text { 7ertanas }\end{array}$ \\
\hline 2 & 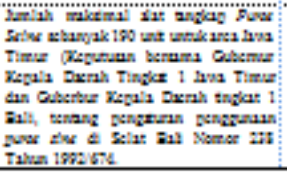 & $\begin{array}{l}\text { Powaind } \\
\text { pelitudan }\end{array}$ & 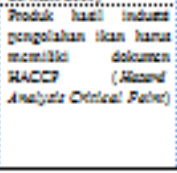 & 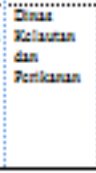 \\
\hline \multicolumn{5}{|c|}{ Inglan Trabl 1} \\
\hline 4 & 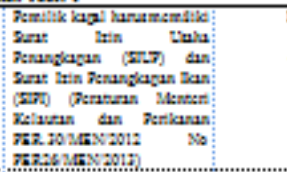 & 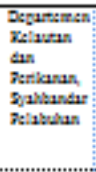 & 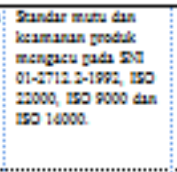 & 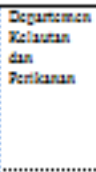 \\
\hline 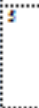 & 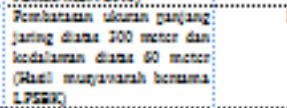 & 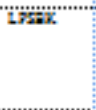 & 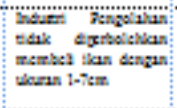 & 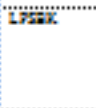 \\
\hline 6 & 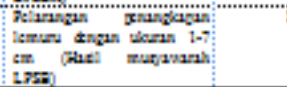 & 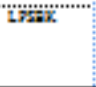 & & \\
\hline
\end{tabular}

lainnya dan klasifikasi sub elemen berdasarkan karakteristik yang dinyatakan dengan daya dorong (driver power) dan kebergantungan (dependent), serta identifikasi elemen kunci dalam analisis rantai nilai hasil tangkapan lemuru untuk bahan baku industri pengolahan ikan.

Hubungan konspetual antara sub elemen pada setiap elemen adalah sebagai berikut :

1. Elemen kendala dalam kegiatan dalam kegiatan lemuru, hubungan konseptualnya adalah sub elemen yang satu berdampak terhadap elemen lainnya.

2. Elemen kebutuhan pelaku usaha di dalam rantai nilai, hubungan konseptualnya adalah sub elemen yang satu mempengaruhi keberlangsungan elemen lainnya.

3. Elemen masyarakat yang terpengaruh di dalam rantai nilai, hubungan konseptualnya adalah sub elemen yang satu memiliki ketergantungan dengan elemen lainnya.

4. Elemen kelembagaan hubungan konseptualnya adalah sub elemen yang satu mendorong sub elemen lainnya 


\section{Elemen Kendala}

Berdasarkan hasil diskusi dengan para pakar, elemen kendala dalam kegiatan perikanan lemuru dapat diuraikan menjadi 7 elemen. Sub elemen yang terdapat pada elemen kendala dalam kegiatan perikanan lemuru adalah :

1. Hasil tangkapan lemuru dari nelayan tidak mencukupi kebutuhan bahan baku industri pengolahan ikan.

2. Kelestarian lemuru terindikasi terancam akibat over fishing.

3. Lemahnya penerapan dan pengawasan Peraturan Menteri Kelautan dan Perikanan Republik Indonesia N0 42/PERMENKP/2014 Pasal 22 ayat 3a tentang ukuran mata jaring alat tangkap purse seine.

4. Kurangnya minat nelayan untuk melakukan operasi penangkapan di luar wilayah Selat Bali.

5. Kebutuhan lapangan kerja yang meningkat untuk anak buah kapal karena hanya sedikit kapal yang beroperasi.

6. Tidal aktifnya koperasi nelayan menyebabkan nelayan tidak memiliki lembaga yang dapat memberikan bantuan pinjaman modal usaha. Lembaga-lembaga yang terkait kurang optimal dalam mewujudkan solusi yang telah dirumuskan

Hasil penilaian para pakar terhadap hubungan konseptual antar sub elemen kendala ini menghasilkan matrik SSIM (Self Struktural Interpretative Structural Matrix) sebagai berikut :

Tabel 2. Matrik SSIM Elemen Kendala

\begin{tabular}{|l|l|l|l|l|l|l|l|}
\hline \multicolumn{7}{|c|}{ Elemen Kebutuhan Pelaku di Dalam Rantai Nilai } \\
\hline & $\mathbf{1}$ & $\mathbf{2}$ & $\mathbf{3}$ & $\mathbf{4}$ & $\mathbf{5}$ & $\mathbf{6}$ & $\mathbf{7}$ \\
\hline $\mathbf{1}$ & & A & A & A & V & O & O \\
\hline $\mathbf{2}$ & & & A & X & V & O & A \\
\hline $\mathbf{3}$ & & & & X & V & O & A \\
\hline $\mathbf{4}$ & & & & & X & O & A \\
\hline $\mathbf{5}$ & & & & & & O & O \\
\hline $\mathbf{6}$ & & & & & & & O \\
\hline $\mathbf{7}$ & & & & & & & \\
\hline
\end{tabular}

Ket : $\mathrm{V}$ jika $\mathrm{e}_{\mathrm{ij}}=1$ dan $\mathrm{e}_{\mathrm{ji}}=0$

$A$ jika $e_{i j}=0$ dan $e_{j i}=1$

$X$ jika $e_{i j}=1$ dan $e_{j i}=1$

$\mathrm{O}$ jika $\mathrm{e}_{\mathrm{ij}}=1$ dan $\mathrm{e}_{\mathrm{ji}}=1$

Kemudian hasil penilaian diatas dikonversi menjadi matrik reachabilty (RM) sehingga diperoleh matrik RM sebagai berikut :
Tabel 3. Matrik RM akhir dan Interpertasi Elemen Kendala

\begin{tabular}{|c|c|c|c|c|c|c|c|}
\hline & 1 & 2 & 3 & 4 & 5 & 6 & 7 \\
\hline 1 & 1 & 0 & 0 & 1 & 0 & 0 & 0 \\
\hline 2 & 1 & 1 & 0 & 1 & 1 & 0 & 0 \\
\hline 3 & 1 & 1 & 1 & 1 & 1 & 0 & 0 \\
\hline 4 & 1 & 1 & 1 & 1 & 1 & 0 & 0 \\
\hline 5 & 0 & 0 & 0 & 1 & 1 & 0 & 0 \\
\hline 6 & 0 & 0 & 0 & 0 & 0 & 1 & 0 \\
\hline 7 & 0 & 1 & 1 & 1 & 0 & 0 & 1 \\
\hline
\end{tabular}

Matrik RM diatas belum memenuhi aturan transivity, oleh karena itu perlu Selanjutnya dilanjutkan pemeriksaan matrik RM agar memenuhi aturan transivity, matrik RM akhir yang sudah memenuhi aturan transivity dan interpertasinya tersaji dalam tabel 4 berikut ini.

Tabel 4. Matrik RM Akhir Elemen Kendala

\begin{tabular}{|l|l|l|l|l|l|l|l|l|l|}
\hline & 1 & 2 & 3 & 4 & 5 & 6 & 7 & $\mathrm{DP}$ & $\mathrm{R}$ \\
\hline 1 & 1 & 0 & 1 & 1 & 1 & 0 & 0 & 4 & 2 \\
\hline 2 & 1 & 1 & 0 & 1 & 1 & 0 & 0 & 4 & 2 \\
\hline 3 & 1 & 1 & 1 & 1 & 1 & 0 & 0 & 5 & 1 \\
\hline 4 & 1 & 1 & 1 & 1 & 1 & 0 & 0 & 5 & 1 \\
\hline 5 & 0 & 0 & 0 & 1 & 1 & 0 & 0 & 2 & 3 \\
\hline 6 & 0 & 0 & 0 & 1 & 0 & 1 & 0 & 2 & 3 \\
\hline 7 & 0 & 1 & 1 & 1 & 1 & 0 & 1 & 5 & 1 \\
\hline$D$ & 4 & 4 & 4 & 7 & 6 & 1 & 1 & & \\
\hline R & 3 & 3 & 3 & 1 & 2 & 4 & 4 & & \\
\hline
\end{tabular}

Dari hasil interpertasi matrik RM akhir diatas maka dapat disusun suatu hirarki keterhubungan antara sub elemen kendala dalam kegiatan perikanan lemuru yang disajikan pada gambar 2 berikut ini.

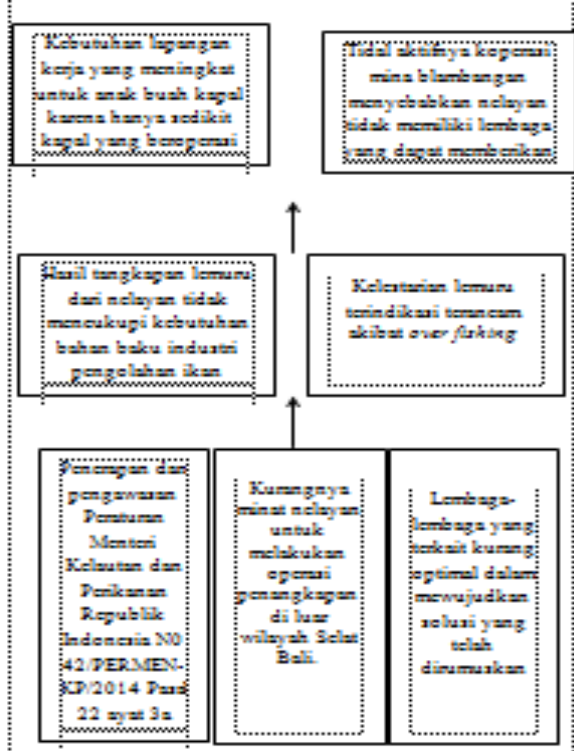

Gambar 2. Struktur hirarki Antar Sub Elemen Kendala 
Gatot Silo Sakti, Hari Rujito dan Rahmat Ali Syaban, Analisis Rantai Nilai Hasil Tangkapan Lemuru Sebagai Bahan Baku Industri Pengolahan Ikan

Pada gambar 12 dapat diketahui bahwa sub elemen (1) hasil tangkapan lemuru dari nelayan tidak mencukupi kebutuhan bahan baku industri pengolahan, (3) penerapan dan pengawasan Peraturan Menteri Kelautan dan Perikanan Republik Indonesia N0 42/PERMEN-KP/2014 Pasal 22 ayat $3 \mathrm{a}$ tentang ukuran mata jaring alat tangkap purse seine dan (7) lembaga-lembaga yang terkait kurang optimal dalam mewujudkan solusi yang telah dirumuskan. mempunyai daya gerak yang besar untuk mempengaruhi sub elemen kendala lainnya. Jika dilihat pada matrik $D P-D$ pada tabel 4, sub elemen 1 dan 3 walaupun memiliki kekuatan penggerak yang besar tetapi juga memiliki ketergantungan yang besar pula terhadap sub elemen lainnya sehingga kedua elemen tersebut penting untuk diperhatikan karena setiap treatment yang dilakukan pada sub elemen 1 dan 3 akan berdampak besar pada sub elemen lainnya. Sedangkan sub elemen 7 memiliki ketergantungan yang lemah terhadap sub elemen lainnya, oleh karena itu sub elemen 7 merupakan prioritas kendala yang penting untuk diselesaikan

Gambar 3, menunjukan posisi setiap sub elemen dalam elemen kendala dalam pengusahaan perikanan lemuru, posisi sub elemen tersebut adalah sebagai berikut : Sub elemen (7) lembagalembaga yang terkait kurang optimal dalam mewujudkan solusi yang telah dirumuskan masuk kedalam sektor IV (Independent). Sub elemen ini merupakan kekuatan penggerak dalam kendala pengusahaan perikanan lemuru tetapi mempunyai hubungan tidak langsung terhadap rantai nilai hasil tangkapan lemuru untuk bahan baku (strong driverweak dependent variables). Sementara itu, sebagian besar sub elemen $(1,2,3,4)$ masuk dalam sektor III (Lingkage), yang berarti sub elemen ini harus dikaji secara hati-hati karena hubungan antara sub elemen tidak stabil. Setiap tindakan pada sub elemen akan memberikan dampak terhadap sub elemen lainnya dan pengaruh umpan baliknya akan memperbesar dampak. Sektor II (Dependent) ditempati oleh sub elemen (5) kebutuhan lapangan kerja yang meningkat untuk anak buah kapal (ABK) karena hanya sedikit kapal yang beroperasi, artinya sub elemen ini merupakan sub elemen yang tidak bebas. Sedangkan sub elemen (6) Tidak aktifnya koperasi nelayan menyebabkan nelayan tidak memiliki lembaga yang dapat memberikan bantuan pinjaman modal usaha masuk kedalam sektor I (Autonomus). Sub elemen pada sektor ini umumnya tidak berkaitan atau memiliki sedikit hubungan dengan sistem

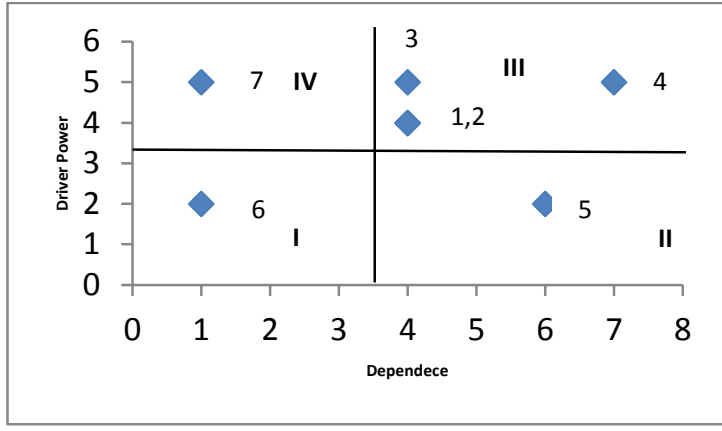

Ket $: \mathrm{I}=$ Autonomos, $\mathrm{II}=$ Dependent, $\mathrm{III}=$ Lingkage, $\mathrm{IV}=$ Independent

\section{Gambar 3. Matrik Driver Power-Dependence Elemen Kendala}

\section{Elemen Kebutuhan Pelaku Usaha di Dalam Kegiatan Perikanan Lemuru}

Berdasarkan hasil analisis ISM pada tabel 19, sub elemen (2) Tata kelola, regulasi dan pengawasan, (3) Penyuluhan dan Pembinaan (4) Solusi dari peraturan yang ada dan (5) Kelembagaan yang aktif merupakan sub elemen kunci dari elemen kebutuhan pelaku usaha dalam kegiatan perikanan lemuru, berdasarkan nilai driver power (penggerak) yang tinggi dan dependent (ketergantungan) yang tinggi pula ke empat sub elemen tersebut masuk ke sektor III (linkage). Sub elemen pada sektor ini memiliki hubungan yang erat dengan sub-sub elemen lainnya, sehingga strategi pemenuhan kebutuhan pelaku usaha dalam kegiatan lemuru perlu mempertimbangkan sub elemen lain dalam perumusannya. hal ini sejalan dengan penelitian yang dilaksanakan Joesidawati et al (2004). Dari hasil penelitian tersebut diketahui bahwa masyarakat muncar membutuhkan alternatif pengelolaan, peran aktif pengelola perikanan lemuru, penyempurnaan regulasi dan penerapan MCS (Monitoring), Controlling (MSC), dan Pengawasan (Surveillance) dalam kegiatan perikanan lemuru.

Sektor dependent di isi oleh sub elemen (1) Ketersediaan lemuru sebagai bahan baku, (6) ketersediaan modal, (7) penerapan teknologi. Pada sektor ini sub elemen memiliki tingkat kebergantungan yang tinggi terhadap sistem, ke tiga sektor ini memerlukan perhatian dan intervensi dari pemerintah dalam pemenuhannya. Berdasarkan hasil wawancara dengan kepala Dinas Kelautan dan Perikanan Kabupaten Muncar, Kepala UPT Pelabuhan Perikanan Muncar dan mengacu pada hasil musyawarah bersama lembaga pengelola perikanan berbasis komoditas (LPSBK), terdapat beberapa alternatif kebijakan yang 
mewakili keseluruh elemen kebutuhan pelaku dalam kegiatan perikanan lemuru, yaitu :

1. Penerapan open season dan close season pada penangkapan lemuru.

2. Melarang penangkapan lemuru berukuran kurang dari $8 \mathrm{~cm}$.

3. Perusahaan pengolahan ikan di larang membeli lemuru kurang dari $8 \mathrm{~cm}$.

4. Pengalihan fishing ground ke wilayah ZEE (Zona Ekonomi Eksklusif).

5. Pengadaan armada percontohan untuk beroperasi ke wilayah ZEE oleh Kementerian Kelautan dan Perikanan melalui Departemen Kelautan dan Perikanan Kabupaten Banyuwangi.

6. Mengadakan penyuluhan dan pembinaan tenntang tata cara penangkapan dan teknologi yang dibutuhkan untuk beroperasi di area ZEE dari Departemen Kelautan.

7. Revitalisasi sarana pelabuhan agar memiliki kompetensi wisata

8. LPSBK menjadi lembaga yang aktif dalam membangun usaha perikanan yang kuat dan bertanggung jawab.

9. Perlu adanya lembaga PERBANKAN nelayan yang efektif.

Tabel 5. Hasil Analisis ISM Elemen Kebutuhan

\begin{tabular}{|c|c|c|c|c|c|}
\hline No & $\begin{array}{l}\text { Sub } \\
\text { elemen }\end{array}$ & $D P$ & $D$ & $R$ & Sektor \\
\hline 1 & $\begin{array}{l}\text { Ketersediaanlem } \\
\text { urusebagaibahan } \\
\text { baku }\end{array}$ & 2 & 6 & 3 & II \\
\hline 2 & $\begin{array}{l}\text { Tata kelola, } \\
\text { regulasi dan } \\
\text { pengawasan }\end{array}$ & 7 & 4 & 1 & III \\
\hline 3 & $\begin{array}{l}\text { Penyuluhandanp } \\
\text { embinaan }\end{array}$ & 7 & 4 & 1 & III \\
\hline 4 & $\begin{array}{l}\text { Solusidariperatu } \\
\text { ran yang ada }\end{array}$ & 7 & 4 & 1 & III \\
\hline 5 & $\begin{array}{l}\text { Kelembagaan } \\
\text { yang aktif }\end{array}$ & 7 & 4 & 1 & II1 \\
\hline 6 & $\begin{array}{l}\text { Ketersediaan } \\
\text { modal }\end{array}$ & 2 & 7 & 3 & 11 \\
\hline 7 & $\begin{array}{l}\text { Penerapanteknol } \\
\text { ogi }\end{array}$ & 3 & 6 & 2 & I1 \\
\hline
\end{tabular}

\section{Elemen Masyarakat yang Terpengaruh}

Berdasarkan hasil analisa ISM elemen masyarakat yang terpengaruh, diketahui sebagian besar sub elemen masuk ke dalam sektor III. Sub elemen yang berdaya gerak besar dalam elemen ini adalah sub elemen (1) nelayan pemilik kapal dan (2) nelayan ABK, kedua elemen ini masuk ke dalam sektor III (linkage). Walaupun sub elemen tersebut memiliki daya gerak yang besar, tetapi juga memiliki ketergantungan yang besar terhadap sub elemen lainnya. Oleh karena itu sub elemen pada sektor ini harus ditangani secara serius.
Sub elemen (7) Pedagang kecil/eceran memiliki ketergantungan yang tinggi terhadap sub elemen lain (dependent). Pada umumnya pedagang kecil bergantung pada nelayan dalam memasok ikan untuk di jual kembali. Oleh karena itu produktifitas nelayan sangat berkaitan erat dengan kelangsungan usaha pedagang kecil. Sehingga kebijakan yang tepat sasaran bagi nelayan, maka akan berdampak positif pula bagi kelangsungan usahapedagang kecil/eceran

Tabel 6. Hasil Analisis ISM Elemen Masyarakat yang Terpengaruh

\begin{tabular}{|c|c|c|c|c|c|}
\hline No & Sub elemen & $D P$ & $D$ & $\mathrm{R}$ & Selktor \\
\hline 1 & $\begin{array}{l}\text { Delayanpemilitik. } \\
\text { apgl }\end{array}$ & 7 & 4 & 1 & III \\
\hline 2 & $\begin{array}{ll}\text { Nelayan } & \text { ABK } \\
\text { (Anak } & \text { Buah } \\
\text { Kapal) } & \end{array}$ & 7 & 4 & 1 & IIII \\
\hline 3 & $\begin{array}{l}\text { Pengus hard dyat } \\
\text { ipengolahanikan. }\end{array}$ & 5 & 6 & 2 & IIIII \\
\hline 4 & $\begin{array}{l}\text { Tenag alketindus } \\
\text { tripengolahan }\end{array}$ & 5 & 6 & 2 & IIII \\
\hline 5 & MasY Arakatselita & 5 & 6 & 2 & IIII \\
\hline 6 & Blopoptif. & 3 & 6 & 4 & IiII \\
\hline 7 & $\begin{array}{l}\text { Pedagang } \\
\text { kecil/eceran }\end{array}$ & 4 & 4 & 3 & III \\
\hline
\end{tabular}

\section{Elemen Kelembagaan}

Sub elemen yang berada pada sektor independent adalah sub elemen kunci pada struktur hirarki elemen kelembagaan, sub elemen tersebut adalah : (1) DKP dan (2) UPT Pelabuhan Perikanan Muncar. Kedua sub elemen tersebut memiliki faktor penggerak tinggi dan memiliki ketergantungan yang rendah terhadap sub elemen lainnya. Oleh karena itu kedua sub elemen ini merupakan elemen kunci yang memiliki tanggung jawab dalam menaungi sub elemen lainnya.

Sedangkan sub elemen (8) Syahbandar dan (9) POLAIR walaupun memiliki nilai penggerak yang besar dan ketergantungan yang randah, masuk ke dalam sektor III yang posisinya berdekatan dengan sektor IV, yang artinya walaupun kedua lembaga tersebut memiliki kebijakan dan tata aturan tersendiri tetapi kedua sub elemen tersebut masih memiliki ketergantungan kepada DKP dan UPT Pelabuhan Perikanan khususnya mengenai informasi dan data peraturan dan perundangundangan perikanan yang berlaku. Sub elemen pada sektor linkage yang lain adalah kelompok nelayan, HNSI, LPSBK, APPI dan lembaga peneliti, sub elemen tersebut membutuhkan dukungan dari DKP dan UPT Pelabuhan Muncar dalam melaksanakan tata cara dan aktivitas organisasinya. 
Gatot Silo Sakti, Hari Rujito dan Rahmat Ali Syaban, Analisis Rantai Nilai Hasil Tangkapan Lemuru Sebagai Bahan Baku Industri Pengolahan Ikan

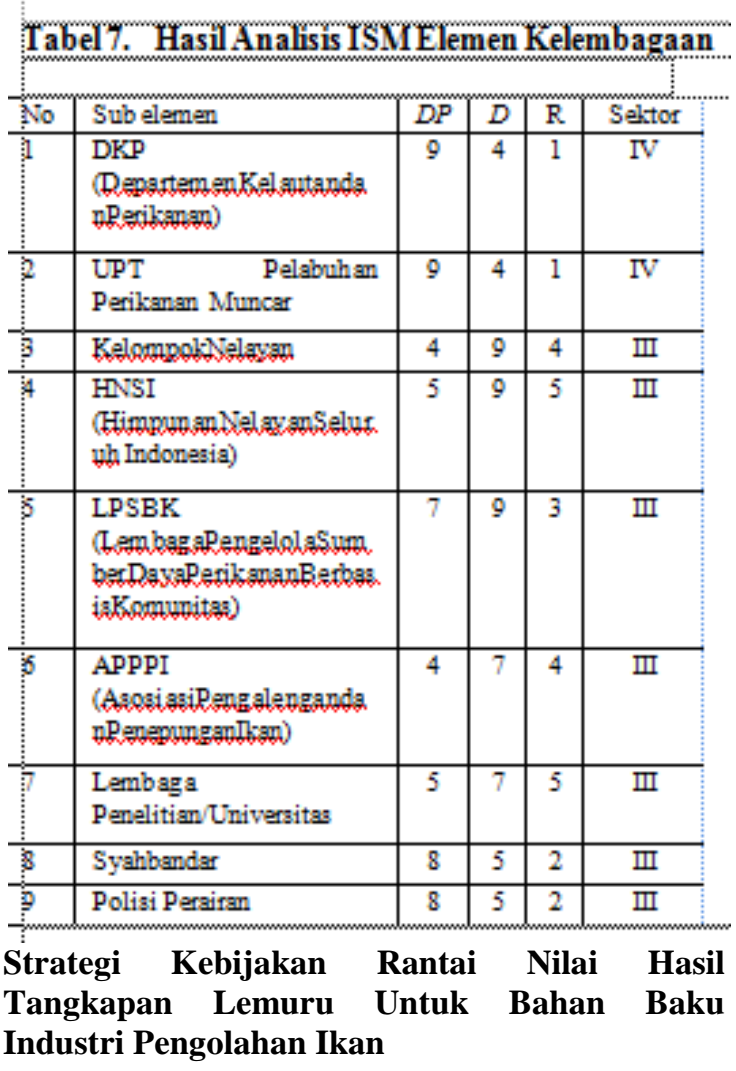

Berdasarkan kajian mendalam dengan para pakar maka diperoleh struktur hierarki strategi Kebijakan Rantai Nilai Hasil Tangkapan Lemuru Untuk Industri Pengolahan Ikan. Struktur hirarki Strategi kebijakan terdiri dari tiga level, level pertama adalah fokus (goal), level kedua adalah kriteria kebijakan dan yang ketiga adalah alternatif kebijakan.

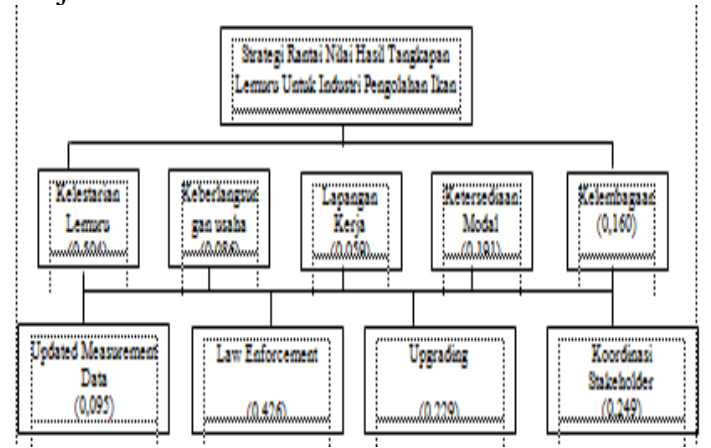

Gambar 4. Struktur Hirarki AHP

\section{Hubungan Antara Alternatif Kebijakan dengan Kriteria Kebijakan}

Tabel 9, menunjukan hubungan antara alternatif kebijakan dengan kriteria kebijakan. Pada kriteria kebijakan kelestarian lemuru law enforcement (penegakan hukum) merupakan alternatif kebijakan yang paling mempengaruhi, dengan bobot 0,692. Law enforcement merupakan hal penting yang perlu diterapkan untuk

\section{Hubungan Antara Kriteria Kebijakan dengan Sasaran (Goal) \\ Kriteria kebijakan yang dianggap paling} penting dalam rantai nilai adalah kelembagaan dengan bobot 0,472 . Kelembagaan begitu penting karena arah kebijakan yang dibuat akan di koordinasikan oleh lembaga-lembaga yang terkait. Oleh karena itu kebutuhan untuk kelembagaan yang kuat sangat diperlukan dalam rantai nilai hasil tangkapan lemuru untuk industri pengolahan ikan .

koordinasikan oleh lembaga-lembaga yang terkait. Oleh karena itu kebutuhan untuk kelembagaan yang kuat sangat diperlukan dalam rantai nilai hasil tangkapan lemuru untuk industri pengolahan ikan .

\begin{tabular}{llll} 
Tabel. 8 & $\begin{array}{l}\text { Hubungan } \\
\text { Dengan Goal }\end{array}$ & Kriteria & Kebijakan \\
\cline { 1 - 1 } \cline { 1 - 1 } Kriteria & & Strategi Rantai Nilai \\
\hline Kelestarian lemuru & 0,504 \\
Keberlangsungan usaha & 0,086 \\
Lapangan kerja & 0,059 \\
Ketersediaan modal & 0,191 \\
Kelembagaan & 0,160 \\
\hline
\end{tabular}

$\begin{array}{lrr}\text { mewujudkan } & \text { perikanan } & \text { yang } \\ \text { berkelanjutan.Menurut } & \text { penelitian } & \text { yang }\end{array}$ dilaksanakan Kementerian PPN/BAPPENAS (Tanpa Tahun), rendahnya law eforcement akan mengakibatkan perairan laut di suatu daerah akan mengalami tahap over exploitation, yang mengakibatkan nelayan-nelayan mengalami kemiskinan karena sulitnya mendapatkan tangkapan.

Upgrading merupakan alternatif kebijakan yang paling mempengaruhi pada kriteria kebijakan keberlangsungan usaha, dengan bobot 0,563. Menurut hasil wawancara dengan pakar, terdapat beberapa opsi upgrading dalam bidang penangkapan yang berkelanjutan, yaitu penerapan open season dan close season pada penangkapan lemuru dan pengalihan fishing ground ke wilayah ZEE (Zona Ekonomi Eksklusif).

Pada kriteria kebijakan lapangan kerja, alternatif kebijakan upgrading merupakan yang paling berpengaruh dengan bobot 0,519. Pengadaan lapangan kerja begitu penting direncanakan untuk mencegah kemiskinan struktural pada kalangan nelayan buruh/Anak Buah Kapal (ABK). Pamungkas (2013) Dalam hasil penelitian yang berjudul Impilkasi Ekonomi dan Sosial Masyrakat pesisir Atas Turunnya Hasil Tangkapan Lemuru. Menyatakan, nelayan pendega (ABK) tidak memiliki alternatif kegiatan produktif lainnya akibat penurunan hasil tangkapan lemuru, sehingga nelayan pendega lebih memilih untuk menjual barang-barang rumah tangganya dan melakukan pinjaman kepada juragannya yang justru semakin mengikat dan menghimpit nelayan pendega pada 
kemiskinan. Melihat hal tersebut Kepala UPT berencana untuk menciptakan alternatif lapangan kerja dengan memanfaatkan fasilitas pelabuhan. Menurut Zainul Hasan pelabuhan Muncar memiliki potensi wisata yang baik, diantaranya : kondisi perairan yang masih baik untuk olahragamenyelamsport fishing dan memanfaatkan dermaga pelabuhan sebagai tempat wisata keluarga. Untuk mewujudkan hal tersebut Pelabuhan Perikanan Muncar saat ini sedang dalam tahap perbaikan infrastruktur, selain itu diperlukan kerja sama dengan lembaga-lembaga terkait lain untuk menyiapkan sumber daya manusia yang berkompeten di industri wisata yang sedang direncanakan.Pada kriteria kebijakan ketersediaan modal, alternatif kebijakan yang paling mempengaruhi adalah koordinasi stakeholder dengan bobot 0,415 . Pemerintah pusat melalui Otoritas Jasa Keuangan (OJK) telah menyediakan alternatif untuk membantu pembiayaan modal nelayan yang accountable, yaitu dengan program lembaga keuangan mikro Nelayan Berdasarkan alur tata cara pendirian dan pengesahan Lembaga Keuangan Mikro, untuk mewujudkan ketersediaan modal bagi pelaku-pelaku usaha mikro (khususnya nelayan) seluruh pihak yang terkait harus berkoordinasi untuk menentukan siapa saja yang berwenang menjadi anggota dalam membuat rencana, tujuan dan seluruh persyaratan yang harus dipenuhi dalam pengajuan pendirian LKM.

Pada kriteria kebijakan kelembagaan, alternatif kebijakan yang paling berpengaruh adalah koordinasi stakeholder dengan bobot 0,525. Lembaga-lembaga di muncar memiliki wadah yang disebut LPSBK (Lembaga Pengelola Sumber Daya Perikanan Berbasis Komunitas) merupakan suatu lembaga non Pemerintah di Muncar, dengan anggota yang terdiri dari : kelompok nelayan, DPD HNSI (Himpunan Nelayan Seluruh Indonesia), Asosiasi Pengalengan dan Penepungan Ikan (APPI), Asosiasi Cold Storge). LPSBK merupakan lembaga yang dibangun untuk menjalin keeratan antar lembaga dan bekerja sama untuk mewujudkan perikanan yang berkesinambungan dan berkelanjutan di daerah Muncar, oleh karena itu peran lembaga ini sangat penting dalam perikanan lemuru. Sedangkan lembaga pemerintah yang terkait terdiri dari Departemen Kelautan dan Perikanan, UPT Pelabuhan Perikanan, Syahbandar dan Polisi Perairan.

\section{KESIMPULAN}

Berdasarkan hasil penelitian "Analisis Rantai Nilai Hasil Tangkapan Lemuru Sebagai Bahan Baku Industri Pengolahan Ikan" dapat diambil beberapa kesimpulan, yaitu :

1. Analisis pemetaan rantai nilai menunjukan adanya ketidakaktifan pengelola Tempat Pelelangan Ikan dalam penentuan harga,
Pelabuhan Perikanan Muncar, Zainul Hasan A.pi, sehingga hasil tangkapan dari nelayan tidak memiliki perlindungan harga dan tidak efektifnya pendataan jumlah hasil tangkapan nelayan yang didaratkan.

2. Analisis tata kelola dan regulasi menunjukan adanya gap antara pemberlakuan PERMEN Kelautan dan Perikanan No.42/PERMEN$\mathrm{KP} / 2014$ tentang ukuran mata jaring purse seine yang diperbolehkan. Pelanggaran yang dilakukan oleh nelayan terjadi karena peraturan yang berlaku tidak sesuai dengan fakta yang ada di lapangan serta tidak adanya alternatif kawasan tangkap lain apabila peraturan tersebut diterapkan.

3. Analisis ISM (Interpretative Structural Modelling) menunjukan terdapat empat elemen yang berpengaruh pada rantai nilai kegiatan perikanan lemuru di Muncar, yaitu : Elemen kendala dalam kegiatan perikanan lemuru dengan sub elemen lembaga terkait kurang optimal dalam mewujudkan solusi yang telah dirumuskan sebagai sub elemen kunci, Elemen kebutuhan pelaku usaha dalam kegiatan perikanan lemuru dengan sub elemen tata kelola, regulasi dan pengawasan, penyuluhan dan pembinaan, solusi dari peraturan yang ada, dan kelembagaan yang aktif merupakan sub elemen kunci, Elemen masyarakat yang terpengaruh dengan sub elemen nelayan pemilik kapal dan nelayan ABK sebagai sub elemen kunci dan sub elemen kelembagaan dengan Dinas Kelautan dan Perikan dan UPT Pelabuhan Perikanan Muncar sebagai elemen kunci.

4. Berdasarkan analisis kebijakan AHP (Analytic Hierarchy Process) kriteria kebijakan yang menjadi prioritas adalah kelesetarian lemuru dengan alternatif kebijakan yaitu law enforcement. Penerapan law enforcement dapat efektif apabila ditunjang kebijakan lain untuk memperkecil gap antara peraturan dengan pelanggaran yang terjadi. Kebijakan alternatif tersebut dapat dikelola secara bertahap dan sinergis, dimulai dari koordinasi stakeholder dalam rangka penguatan modal dengan mendirikan Lembaga Keuangan Mikro Nelayan, penerapan open season dan close season, pengalihan wilayah tangkap untuk nelayan dan diversifikasi bahan baku untuk industri, mengembangkan potensi wisata pelabuhan untuk menyerap angkatan kerja selama kebijakan tersebut direncanakan, dan didukung dengan pembaharuan data pengukuran bioeconomic.

5. Koordinasi dan komitmen dari lembaga Pemerintah maupun non pemerintah serta pelaku-pelaku perikanan, penting untuk dilakukan dalam mewujudkan strategi kebijakan yang akan dilaksanakan. 
Gatot Silo Sakti, Hari Rujito dan Rahmat Ali Syaban, Analisis Rantai Nilai Hasil Tangkapan Lemuru Sebagai Bahan Baku Industri Pengolahan Ikan

\section{DAFTAR PUSTAKA}

ACIAR.2012.

MembuatRantaiNilaiLebihBerpihakpadaK aumMiskin.Australian Centre for Internasional Agricultural Research.Australian Goverment Australia.

BAPPEDA Kabupaten Banyuwangi. 2007. UMKM Indutri pengolahan hasil ikan di Kawasan Muncar.

Dinas Kelautan dan Perikanan Kabupaten Banyuwangi. 2013. Produksi dan Nilai Produksi Produk Perikanan di Kabupaten Banyuwangi.

Hugon. P. 1985. Le miroir sans tain. Dependance alimentaire et urbanisation en Afrque : un essai d'anlyse mesodynamique en termes de filliers. Altersial. CERED and M.S.A. Nourrir Les villes, L'Harmattan : 9 - 46.

Iranawati et al. 2013. Teknik Interpretative Structural Modeling (ISM) Untuk Strategi Implementasi Model Pengelolaan Perikanan Tangkap di Taman Nasional Karimunjawa. Jurnal ilmu pertanian dan perikanan vol 2 No1. Hal 75-86.

KedeputianBidangPencemaran Lingkungan.2007.LaporanAkhirPengelola anLingkunganIndustriPengolahanIkan di Muncar. Banyuwangi.
Kaplinsky, R and M. Morris. 2001. A Handbook for Value Chain Research, Brighton, United Kingdom, Institute of Development Studies, University of Sussex.

Kementerian Koperasi dan Usaha Kecil dan Menengah. 2011. Kebangkitan Koperasi dan UMKM Menuju Kesejahteraan Masyarakat. Laporan Tahunan. Jakarta.

Porter. M. E (1985). Competitive Advantage. New York. The Free Press

Le Goulven, K.,J. P. Bountonner, et al. 1999. Commercialisation d'un Produit Agricoledans un Contexte Economique 'de Transition'. La FiliereViande Porcine de Nam Thanh a HaiPhong. RevneElevage et Medecine Veterinaire des Pays Tropicaux : $305-312$.

Marimin. 2008. Pengambilan Keputusan Kriteria Majemuk. PT Grasindo Widiasarana. Jakarta. 2004

SuharjitodanMarimin. 2008 Model KelembagaanPengembanganIndustriHilir KelapaSawit. Prosiding Seminar NasionalManajemenTeknologi VIII. Surabaya.

Supriatnaet al. 2014. Model Rantai Nilai Pengembangan Perikanan Tuna, Tongkol dan Cakalang di Indonesia .Departemen Pemanfaatan Sumberdaya Perikanan, FakultasPerikanandanIlmuKelautan. InstitutPertanian Bogor. Bogor. 